\title{
Silla's Perception of the International World Order as Seen through Diplomatic Documents
}

Heejoon Choi*

\section{Introduction}

Silla's growth and development were the result of endless diplomatic exchanges with its surrounding states. In particular, with the emergence of the unified empire known as the Tang Dynasty, diplomacy became the main priority with Silla becoming a target for foreign negotiations. In this manner, Silla came to construct a relationship with the Tang Dynasty by actively corresponding with the international world order, represented as the tribute-investiture system, led by the Tang. As a result, most scholarship agrees ${ }^{1}$ with the idea that Silla's perception of the international

* Post-doctoral fellow, Department of History, Dankook University

1 The tribute-investiture relationship in this paper is a ceremonial and formal relationship that an order established by Confucius courtesy is expanded and applied to the international relationship. For the Chinese tribute-investiture relationship with its neighboring states, this paper refers to the following studies.

John K. Fairbank and S. Y. Teng, "On the Ch'ing Tributary System," Harvard Journal of Asiatic Studies 6 (June 1941).

John K. Fairbank, "A Preliminary Framework,” in The Chinese World Order: Traditional China's Foreign Relations, Harvard University Press, 1968).

Nishijima Sadao, "Tou Asia sekai to Sakuhou taisei - roku hachi seiki no Tou Asia (the World of East Asia and Investiture System - East Asia from 5th to 8th century)," Nihon Rekishi (History of Japan) 2 (1962). 
world order was formed within the context of a tribute-investiture relationship, viewing the Tang Dynasty as its suzerain. ${ }^{2}$

Yet there are conflicting views with regard to Silla's perception and establishment of formal relations with neighboring countries that were not officially recognized by the Tang. For example, in the case of Japan, which has the largest number of extant records of their exchanges with both Tang and Silla, there are sections that mention Silla recognizing Japan as a vassal state (藩國) within Silla's independent empire. ${ }^{3}$ Moreover,

Nishijima Sadao, "Tou Asia sekai no keisei (Formation of the World of East Asia)," Sekai Rekishi (World History) 4 (1970).

Kim Han'gyu, "Kodae tongasia segyejilssouŭi kujojŏk t'ǔksŏng (Structural Characteristic of the World Order of the Ancient East Asia)," Tongasia yŏksaŭi hwallyu (Reflux of the East Asian History) (Seoul: Chisiksanŏpsa, 2000).

Peter Yun, "Sŏgu hakkye chogongjedo ironŭi chungguk chungsimjŏk munhwaron pip'an (A Critique of Sinocentric Culturalism of the Tribute System Model), The Journal of Asiatic Studies)," Aseayŏn'gu (The Journal of Asiatic Studies) 45, no.3 (September 2002).

Pang Hyangsuk, "Kodae tongasia ch'aekpongjogongch'ejeŭi wŏnhyŏnggwa pyŏnyong” Hanjung oegyogwan'gyewa chogongch'aekpong (Diplomatic Relationship between Korea and China, and Tribute-investiture) (Seoul: Koguryŏ yŏn'gujaedan, 2005).

Kim Sŏnggyu, "Miguk mit ilbonesŏ chŏnt'ongjunggugŭi segyejilssŏe kwanhan yŏn'gusawa kŭ t'ŭkching pigyo (A survey and comparison between their characteristics of studies on the traditional Chinese world order in America and Japan)," Yǒksamunhwayŏn'gu (Journal of history and culture) 32 (February 2009).

2 Kwŏn Tŏgyŏng, "Nadanggyosǒpsaesouŭi chogonggwa ch'aekpong," Han'guk kodaegukkawa chunggugwangjoŭi chogong ch'aekponggwan'gye, (Seoul: Koguryŏyŏn'gujaedan, 2006).

3 Sakayori Masashi, "Kodai Tou Asia shokoku no kokusai ishiki - chukka ishiki o chushin shite," Rekishigaku kenkyu (Study of History) (November 1982).

Mun Ansik, "Nambukkuksidaeronŭi hŏsange taehayŏ sillawa parhaeŭi ch'ŏnhajilssŏe kiinhan sanghoinsigŭl chungsimŭro," Han'gukkodaesayŏn'gu (The Journal of Korean History) 19 (September 2000); Han'gukkodaesawa malgal(Ancient Korean History and Malgal) (Seoul: Hyean, 2003).

Kim Ch'angsŏk, "T'ongilssillaŭi ch'ŏnhagwan'gwa taeil insik," Yǒksawa hyŏnsil (History and Reality) 56 (June 2005). 
there are some researchers that argue that Silla believed it occupied an equal position with these countries as a neighboring country (隣國) and established relationships accordingly. ${ }^{4}$ In the same vein, the extent of Silla's official awareness and recognition of neighboring countries, such as Parhae, the Kingdom of Podǒk, and T'amna, differs according to researcher.

The framework of foreign relations tends to emphasize the rules and regulations through which countries established bilateral relationships with one another. Within the actual practice of diplomatic negotiations, the ceremonies and rites that are instrumental in establishing relations played an important role. Thus, if the process of establishing relations between two countries differed, a conflict may have occurred due to their differences in opinions on the appropriate formal procedures. In the worst-case scenario, this clash of beliefs led to the severing of diplomatic ties. Thus, the manner in which Silla treated, perceived, and established relations with its neighboring countries within the context of its Tangcentrism is crucial to understanding the history of Silla's foreign relations.

This paper thus focuses on the manner in which Silla officially exchanged and established diplomatic ties with its neighboring countries. In premodern East Asia, a country's diplomatic rights were entirely vested in

In the same context, these studies understand that Parhae, Podŏk and T'amna kingdom were included in Silla's independent 'World' as vassal states.

4 Chŏn Tŏkchae, "Sillaŭi taeoeinsikkwa ch'ŏnhagwan (Shilla's View of Foreign Situations and Its Perception of the Outer World)," Yŏksamunhwayŏn'gu (Journal of history and culture) 20 (June 2004).

Chŏn Tŏkchae, '8segi sillaŭi taeiroegyowa tongasia insik," Ilbonhagyŏn'gu 44 (February 2015).

Yamada Fumito, “Silla sŏngdŏgwangdaeŭi taeilgwan'gyewa wangsŏngguk (Relationship with Japan and 'Wang Seong Guk(王城國)' in King Seong-deok’s(聖德王) Era of Silla), Han'gukkodaesayŏn'gu (The Journal of Korean History) 87 (September 2017).

Choi Hee-joon, "Sillaŭi ilbonsasin yŏngjŏp chŏlch'awa ŭiryejŏk t'ŭkching (Silla's Reception Procedure for Japanese Envoys and Ceremonial Characteristics)," Sillasahakpo 45 (April 2019). 
the sovereign and diplomatic proceedings that were prepared through official diplomatic documents and dispatched through envoys to other sovereigns. Within the Sinocentric international world order of premodern East Asia, the principle of rites (禮) was emphasized - a principle reflected in the remaining fragments of the official diplomatic records. Thus, the official mutual awareness and establishment of diplomatic relations are directly reflected within the documents exchanged between the Silla King and the receiving sovereign. For these reasons, the diplomatic documents exchanged between Silla and its neighboring countries are invaluable resources in discerning Silla's perception of the international world order. Currently, among the diplomatic documents exchanged between the Silla monarch and the sovereigns of its neighboring countries, the extant texts available for analysis are the ones with Tang China, Japan, and Podŏk Kingdom. This paper thereby uses the aforementioned texts as the primary sources for analysis in order to present a scaffold for a more structural understanding of Silla's diplomatic history. Moreover, this paper hopes to contribute to a deeper understanding into the Sinocentric diplomatic system within East Asia that is embodied by the tribute-investiture systems.

\section{Silla's Protocol for Exchanging Diplomatic Documents}

\section{Diplomatic Documents Between Silla and Tang}

First, it is necessary to examine the diplomatic documents exchanged between the Tang Emperor and the Silla King. Tang Liudian (The Great Tang Institutions of Six Administrative Divisions 大唐六典) stipulates approximately seven forms utilized by the Tang Emperor for official documents:

(1) Ceshu (Investiture document, 冊書)

(2) Zhishu (Decree document, 制書)

(3) Weilaozhishu (Decree document for recognition of services 
rendered, 慰勞制書)

(4) Farichi (Imperial letter of the departure day, 發日勅)

(5) Chizhi (Imperial letter, 栜旨)

(6) Lunshichishu (Imperial document for state affairs, 論事勅書)

(7) Chidie (Letter of imperial order, 勅牒). ${ }^{5}$

There are three types of sentences that begin the diplomatic documents sent by the Tang Emperor that can be currently confirmed: "Hunadi jingwen (the Emperor kindly asks, 皇帝敬問)," “Hunadi wen (the Emperor asks, 皇帝問)” or “Chi (imperial order or letter, 勅).” Within the aforementioned forms, the documents stated with "Hunadi jingwen" or "Hunadi jingwen" were called (3) Weilaozhishu, whereas the documents started with "Chi" were corresponded to (6) Lunshichishu. ${ }^{6}$ Originally, 'Zhishu' and 'Weilaozhishu' were called Zhaoshu (Imperial rescript document, 詔書) and 'Weilaozhaoshu (Imperial Rescript for Recognition of Services Rendered)' until the early Tang period. Yet, after Wu Zetian (武 則天) seized power in the government, she made people avoid using Zhao (imperial rescript, 詔), which was a homonym of her first name, Zhao (照), for the tradition of naming taboo. As a result, the name of the Zhaoshu was changed to Zhishu. After the abdication of Wu Zetian, Zhishu again began to be called Zhaoshu but in reality, the terminology of Zhishu and Zhaoshu were both used afterwards.

Although Weilaozhishu's introduction begins with "Hunadi jingwen (or Hunadi wen) and 某 (referring a name),” Zhishu begins with "Menxia (門 下)."7 This is because in the case of Zhishu, it begins with “門下” in order to give advice, but in the case of Weilaozhishu where the emperor directly

5 Tang Liudian 9, Zhongshusheng (the Secretariat), Chungsŏ Ryŏng (Director of the Secretariat), “凡王言之制有七 一曰冊書 二曰制書 三曰慰勞制書 四曰發日敕 五曰栜旨 六曰論事勅書 七曰敕牒”.

6 Nakamura Hiroichi, Toudai Sei chou kenkyu (Study of Zhi and Chi during the Tang Dynasty Period), (Kyuukoshoin, 1991).

7 Nakamura Hiroichi, Zui Tou ougen no kenkyu (Study of the King's Words in Sui and Tang dynasty), (Kyuukoshoin, 2003). 
questions the recipient, the “皇帝敬問 某” form is selected. Thus, it is possible to ascertain that Weilaozhishu, sent individually, did not receive review and was sent in the form of basic official documents. This was also the case for Lunshichishu which would begin with "Chi."

The emperor's diplomatic documents were generally comprised of the following narratives. The introduction (頭辭) included greetings and praise for the receiving monarch along with a narration that testified to the sender's continued sincerity in serving the emperor in the meantime. This was an exceedingly formal and ceremonial portion. In the body of the text, pending issues on foreign relations are described in detail. In the conclusion, after the sender requests the emperor to grace the writer with his kindness, the partner country would formally dedicate their tribute and would detail the goods that they would bestow, thereby concluding the message. ${ }^{8}$

Nevertheless, the majority of these records are excerpted from diplomatic documents concerned with a particular issue, making it difficult to confirm the contents of the entire passage. In particular, the majority comprises of China's diplomatic documents that are expressed in the Zhaoshu form and are generally related to the subordinate relationship, which are fragmentary and formal. This is also the case for the diplomatic documents sent from the Tang to Silla, but fortunately, a few of the diplomatic documents contain entire sentences. Also their format and content are important materials for analysis. The following historical record A is the introduction of the document entitled "One Consolation Imperial Rescript for the King of Silla in the Years of Zhenguan (貞觀年中撫慰新羅王 詔一首)" sent by Emperor Taizong of Tang to King Sŏndŏk of Silla in the year $645 \mathrm{CE}$.

8 Kim Chongwan, Chunggungnambukchosayŏn'gu - chogong kyobinggwan'gyerŭl chungsimüro (Seoul: Iljogak, 1995), 106-107.

Hwang Wiju, "Parhae oegyomunsouŭi silssanggwa kŭ munch'ejŏk t'ŭkching (The real states of diplomatic documents of Balhae (渤海) and the characteristics of their literary styles)," Taedonghanmunhak 26 (June 2007): 217-218. 
A. 皇帝問柱國樂浪郡王新羅王金善德 朕祈膺靈命 君臨區宇 矜惕 之懷 無忘於風夜 撫育之志 寧隔於遐爾 萬方有罪 情深納隍一 物失所 坐以待且 ${ }^{9}$

With the use of the phrase "Hunadi wen [the recipient's name]" to begin the document, we can ascertain that it is a document issued in Weilaozhishu (Zhaoshu) format. In instances where the Tang Emperor transmitted a document in which he was the superior and the receiver was subordinate, he would use the introductory phrase "Hunadi wen" that was characteristic of Weilaozhishu. In cases where the relationship was equal or independent, he would use "Hunadi jingwen."10 In addition, when the Emperor referred to himself, he would use the appellation "his majesty (朕),” an expression which was a prerequisite for the superior/subordinate relationship. That is, document A's form explicitly demonstrates that the relationship between the Tang Emperor and the Silla King was recognized as that of a vassal and liege.

There are currently four imperial rescripts that still contain the full text exchanged between the Tang Emperor and the Silla King. ${ }^{11}$ In order to examine this form, let us examine the following excerpt:

9 Wenguan Cilin 664, 貞觀年中撫慰新羅王詔一首.

10 Kaneko Shuichi, “Toudai no kokusai bunsho keishiki nit suite," Shigaku zatsushi 83 (1974).

11 The imperial rescripts in the full text from the Tang Emperor to the Silla King are listed in the following table:

\begin{tabular}{l|c|c|c|c}
\multicolumn{1}{c|}{ Document Name } & Date & Sender & Recipient & \multicolumn{1}{c}{ Original Source } \\
\hline $\begin{array}{l}\text { "Imperial letter to the Silla King } \\
\begin{array}{l}\text { Kim Hŭnggwang } \\
\text { (敕新羅王金興光書)" }\end{array}\end{array}$ & $734 \mathrm{CE}$ & $\begin{array}{c}\text { Emperor } \\
\text { Xuanzong }\end{array}$ & $\begin{array}{c}\text { King } \\
\text { Sŏngdŏk }\end{array}$ & $\begin{array}{l}\text { Quan Tang Wen (The } \\
\text { Complete Prose Works of } \\
\text { the Tang Dynasty) 284 }\end{array}$ \\
$\begin{array}{l}\text { "Imperial letter to the Silla King } \\
\text { Kim Hŭnggwang" }\end{array}$ & $735 \mathrm{CE}$ & $\begin{array}{c}\text { Emperor } \\
\text { Xuanzong }\end{array}$ & $\begin{array}{c}\text { King } \\
\text { Sŏngdŏk }\end{array}$ & Quan Tang Wen 285 \\
$\begin{array}{l}\text { "Imperial letter to the Silla King } \\
\text { Kim Hŭnggwang" }\end{array}$ & $736 \mathrm{CE}$ & $\begin{array}{c}\text { Emperor } \\
\text { Xuanzong }\end{array}$ & $\begin{array}{c}\text { King } \\
\text { Sŏngdŏk }\end{array}$ & Quan Tang Wen 285 \\
$\begin{array}{l}\text { "Imperial letter to the Silla King } \\
\text { Kim Chunghŭi (敕新羅王金重熙書)" }\end{array}$ & $810 \mathrm{CE}$ & $\begin{array}{c}\text { Emperor } \\
\text { Xianzong }\end{array}$ & $\begin{array}{c}\text { King } \\
\text { Aejang }\end{array}$ & Quan Tang Wen 284 \\
\hline
\end{tabular}


B. [I] Hereby bestow an imperial rescript to Kim Hŭnggwang (金興光), Grand Commander of Kyerim Province (鷄林州大都督) and King of Silla.

Envoys come in every year and tributes continue. Even if the vast sea blocks you from coming to us, you are no different from China, and courtesies and attire are the same as us. It is because you are polite and hard-working like this, with your sincere loyalty and faithfulness. His majesty (the emperor of Tang) always commends his subjects for their good deeds and respects their ranks. He believes you are keeping your devotion even if you are far from here. When your envoys came to this land, there were many incidents. They suddenly fell ill and never recovered because they were not used to our customs and the food did not agree with them. Thinking about the deceased, he cannot help but believe it was their destiny. He assumes that you mourned their death after hearing this sudden news. He will accept the requests in the memorial. As the early summer is getting hotter, he wishes you and your servants' wellness. There are many things he could not express even if he sends a letter. ${ }^{12}$

This is a rescript written by Zhang Jiuling (張九齡) under the order of Emperor Xuanzong of Tang (唐玄宗 685-762). As there is no direct evidence indicating the date, it is hard to suggest the exact time period this rescript was written. Nevertheless, the phrases such as, "When your envoys came to this land, there were many incidents" and "early summer" provide a clue into estimating the time period this document was written.

12 Quan Tang Wen 285, 敕新羅王金興光書, “敕鷄林州大都督新羅王金興光 比歲使來 朝貢相繼 雖隔滄海 無異諸華 禮樂衣冠 亦在此矣 皆是卿率心忠義 能此恭勤 朕每嘉之 常優等數 想卿在遠 應體至懷 頃者彼處使來 累有物故 水土不習 飲食異宜 奄忽爲災 遂至不救 言念逝者 此其命乎 想卿乍聞 應以傷悼 所以表奏 皆依來請 夏初漸熱 卿及吏人 竝平安好 今有少物 竝付來使 至宜領取 遣書指不多及” 
The former indicates the deaths of the Silla Envoys, Kim Chiryŏm (金志 廉), Kim Úijil (金義質), and Kim Choyŏng (金祖英), while the latter indicates April in terms of the time. Previous scholarship has utilized such facts to estimate the time that this document was written as the $35^{\text {th }}$ year of King Sŏngdŏk's reign (approximately $736 \mathrm{CE}$ ). ${ }^{13}$ Moreover, the introductory phrase, "Kim Hŭnggwang, Grand Commander of Kyerim Province and King of Silla (敕鷄林州大都督新羅王金興光)" of the document lets us know that this document is in the Lunshichishu, one of the forms of the official documents that the Tang Emperor used. Here as well, within the original text, when the Tang Emperor referred to himself, he used the phrase "his majesty (朕)" and when referring to the Silla King, the expression "Qing (Sir, 卿)" was used. Like the aforementioned Weilaozhishu, this expression indicates the relationship between the Emperor and his vassals as one between subordinates and superiors.

On one hand, it was a basic protocol for the monarchs of neighboring countries to use the memorial (表) form like the officials within the Tang's boundary (內臣) whenever they sent documents to the Tang Emperor. Silla was no different in this aspect and dutifully followed this principle as well. The substance of the memorial's (表) form can be roughly divided into three parts. The introduction includes formal greetings and thereby extols the emperor's virtuous achievements and deeds, along with expressing admiration for them. The body of the document introduces the dispatched party's Leader Envoy (正使) and Deputy Envoy (副使) and by giving a brief account of the state of the envoys' country, they explain the envoys' personal backgrounds and trace the purpose of their visit. Finally, in the conclusion, they reconfirm their true and loyal heart and mention the presentation of their tribute. In documents written in the memorial (表) style, the King would refer to himself as "your servant (臣)” and would use a variety of phrases such as “Emperor (皇帝),”

13 Kim Chongpok, "Silla's Diplomatic Tactics in Using Tensions Between Balhae and Tang in the Early 8th Century," The Daegu Historical Review 126 (February 2017): 27-28. 
“Son of Heaven (天子)," and "Your Majesty (陛下)" whenever referring to the Tang Emperor. ${ }^{14}$

In the Dongwenxuan (Anthology of Korean Literary Works in Chinese, 東文選) and Samguk sagi (The History of the Three Kingdoms 三國史記), there are numerous memorials to the throne(表文) written by Ch'oe Ch'iwŏn written on behalf of the Silla King to send to the Tang Emperor. In the $11^{\text {th }}$ year of King Hŏngang of Silla (approx. $885 \mathrm{CE}$ ), Ch'oe Ch'iwŏn was appointed as Sidok (Reader-in-waiting, 侍讀), Hallim Haksa (Hallim Academician, 翰林學士), Su Pyŏngbusirang (守兵部侍郎 Acting Vice Director of the Military Affairs Ministry), and Chisŏsŏgam (知瑞書 監) after he returned from Tang China and compiled these documents at the command of the king. ${ }^{15}$ These memorials to the throne (表文)'s were also written during the same time as these other documents. There are eight memorials in the Dongwenxuan and a total of two in Samguk sagi.

Among the writings in the Dongwenxuan, the author of "A Rescript of Paekche Sending an Envoy to the Court of the North Wei (百濟遣使朝北魏 表)” is indicated as Ch'oe Ch'iwŏn. However, the time periods of the background of this writing and Ch'oe Ch'iwŏn's activities do not match, so it is difficult to absolutely state that he is the author of this text. Thus, it is more accurate to say that the currently remaining texts of Ch'oe Ch'iwŏn's memorials to the throne are seven from the Anthology of Korean Literary Works in Chinese and two from Samguk sagi a total of nine. ${ }^{16}$ The year in which the memorials were written, their sender, recipient, the first sentence of these documents, etc. are detailed in Table 1.

14 Kim Chongwan, Chunggungnambukchosayŏn'gu, 106-107.

15 Ch'oe Kwangsik, "haeje ch'oech'iwŏn'gwa kyewŏnp'ilgyŏngjip," Koun ch'oech'iwŏn sŏnsaeng munjip 1 (2016), 37-38.

16 Ch'ae Miha, "chinsŏngwang chŏnhuŭi oegyomunsŏwa silla (Diplomatic Documents Before and After the Reign of King Jinseong in Silla)," Han'guksayŏn'gu (Journal of Korean History) 179 (December 2017): 111-112. 
Table 1. Memorials to the Throne (表文) written by Ch'oe Ch'iwŏn during the Later Period(下代) of Silla

\begin{tabular}{|c|c|c|c|c|c|}
\hline $\begin{array}{c}\text { Document } \\
\text { Name }\end{array}$ & $\begin{array}{c}\text { Year } \\
\text { Written }\end{array}$ & Sender & Recipient & $\begin{array}{c}\text { First Sen- } \\
\text { tence }\end{array}$ & Original Source \\
\hline 謝追贈表 & $891 \mathrm{CE}$ & $\begin{array}{c}\text { Queen } \\
\text { Chinsŏng }\end{array}$ & $\begin{array}{l}\text { Emperor } \\
\text { Zhaozong }\end{array}$ & 臣坦言 & Samguk sagi, 11 \\
\hline $\begin{array}{c}\text { 謝賜詔書 } \\
\text { 兩函表 }\end{array}$ & $891 \mathrm{CE}$ & $\begin{array}{c}\text { Queen } \\
\text { Chinsŏng }\end{array}$ & $\begin{array}{l}\text { Emperor } \\
\text { Zhaozong }\end{array}$ & 臣某言 & Dongwenxuan, 33 \\
\hline 納権節表 & $893 \mathrm{CE}$ & $\begin{array}{c}\text { Queen } \\
\text { Chinsŏng }\end{array}$ & $\begin{array}{l}\text { Emperor } \\
\text { Zhaozong }\end{array}$ & $\cdot$ & Samguk sagi, 11 \\
\hline 起居表 & $897 \mathrm{CE}$ & $\begin{array}{c}\text { Queen } \\
\text { Chinsŏng }\end{array}$ & $\begin{array}{l}\text { Emperor } \\
\text { Zhaozong }\end{array}$ & 臣某言 & Dongwenxuan, 39 \\
\hline 讓位表 & 897CE & $\begin{array}{c}\text { Queen } \\
\text { Chinsŏng }\end{array}$ & $\begin{array}{l}\text { Emperor } \\
\text { Zhaozong }\end{array}$ & 臣某言 & Dongwenxuan, 43 \\
\hline 謝嗣位表 & $\begin{array}{c}897- \\
898 \mathrm{CE}\end{array}$ & $\begin{array}{c}\text { King Hy- } \\
\text { ogong }\end{array}$ & $\begin{array}{l}\text { Emperor } \\
\text { Zhaozong }\end{array}$ & 臣某言 & Dongwenxuan, 33 \\
\hline 謝恩表 & $\begin{array}{c}897- \\
898 \mathrm{CE}\end{array}$ & $\begin{array}{c}\text { King Hy- } \\
\text { ogong }\end{array}$ & $\begin{array}{l}\text { Emperor } \\
\text { Zhaozong }\end{array}$ & 臣某言 & Dongwenxuan, 33 \\
\hline $\begin{array}{c}\text { 新羅賀 } \\
\text { 正表 }\end{array}$ & $\begin{array}{l}897- \\
898 \mathrm{CE}\end{array}$ & $\begin{array}{c}\text { King Hy- } \\
\text { ogong }\end{array}$ & $\begin{array}{l}\text { Emperor } \\
\text { Zhaozong }\end{array}$ & 臣某言 & Dongwenxuan, 31 \\
\hline $\begin{array}{l}\text { 謝不許北 } \\
\text { 國居上表 }\end{array}$ & $\begin{array}{c}897- \\
898 \mathrm{CE}\end{array}$ & $\begin{array}{c}\text { King Hy- } \\
\text { ogong }\end{array}$ & $\begin{array}{l}\text { Emperor } \\
\text { Zhaozong }\end{array}$ & 臣某言 & Dongwenxuan, 33 \\
\hline
\end{tabular}

Out of the total of nine memorials to the thrones that Ch'oe Ch'iwŏn wrote, only a portion of the main body of the two ("Sach'ujüngp'yo (Memorial of Appreciation for Bestowment of Posthumous Title, 謝追贈表)" and "Memorial before Succeeding the Throne (Napchŏngjŏlp'yo, 納旌節 表)") written in The History of the Three Kingdoms remains. With the first 
phrase of "Sach'ujŭngp'yo" as "Sint'anŏn (your servant T'an says, 臣坦 言)", we can guess at the main topic of the document but in Napchŏngjŏlp'yo, the phrase that would normally convey this information is missing and we are thereby unable to confirm its contents. Nevertheless, the rest of Ch'oe Ch'iwŏn's writings begin with the phrase "Sinmoŏn (Your servant [the recipient's name] says, 臣某言).” We can confidently assume that Napchŏngjŏlp'yo also would have begun with “臣某言” and "Sint'anŏn."17

These two phrases in the introduction of the memorials to the throne are a continuation of the phrases “皇帝(敬)問 某” seen in the previously examined introduction of Weilaozhishu's of the emperor. In the Tangliudian (Six Decrees in the Tang Dynasty 唐六典), in the chapter of the Palace Attendant (侍中), the Chancellery (Menxiasheng, 門下省), “Sinmoŏn must be written" is explained thus, ${ }^{18}$ and we can thereby see that the memorials sent by the Silla King to the Tang Emperor align with the format of documents sent by officials to the Emperor.

This directly shows that the Silla King, in his official diplomatic exchanges with the Tang Emperor, conducted himself as a vassal servant (藩臣) on his own accord. Moreover, as shown in our above examination of how the Tang Emperor used and took into consideration the form of Weilaozhishu in his documents sent to the Silla King, it is likely that Tang and Silla established their relations as one between an empire and a vassal.

\section{Diplomatic Documents between Silla and Japan}

Historical records from Classical Japan contain various diplomatic documents sent by the Emperor of Japan to Silla and the Kingdom of Parhae. These documents begin with the phrase: “天皇敬問.” This is because

17 The estimation of the date Ch'oe Ch'iwŏn wrote each memorials in the table cited Ch'ae Miha, Ibid.

18 Tang Liudian 8, Menxia Sheng (the Chancellery, 門下省), Shizhong (Director of the Chancellery，侍中), “表者上言臣某言下言臣某誠惶誠恐頓首頓首死罪死罪”。 
Classical Japan also utilized the Weilaozhishu form in their diplomatic documents. In the chapter of Nakatsukasa-sho (Procedure of the Ministry of the Center，中務省式) of the Engishiki (Procedures of the Engi Era，延 喜式) there was a prescribed format for the Weilaozhishu started with "the Emperor of Heaven kindly asks (天皇敬問)”. For this part, there was a footnote that states "for a large vassal state, it begins with 'the Emperor of Heaven kindly asks(天皇敬問)', while it starts with 'the Emperor of Heaven asks (天皇問)' for a document to a small vassal state.”

Of the diplomatic documents that the Japanese Emperor sent to the king of Silla, there are a total of three documents with full text as a quotation in complete records with The Shoku Nihongi (続日本紀)'s articles. These include 天皇敬問新羅 ${ }^{19}$ sent in January of $706 \mathrm{CE}$, “天皇敬問新羅國 王”20 sent in November of $706 \mathrm{CE}$, and 天皇敬問新羅國王 ${ }^{21}$ sent in February $780 \mathrm{CE}$. As can be inferred through the title of these documents, all three of these diplomatic documents were written in the Weilaozhishu form. In the same way that we saw Tang's writings as indicative of its position as an empire with Silla as its subordinate, Japan's documents also reveal that it perceived Silla to be a vassal state.

In reality, through Japan's promulgation of the Taiho Code in $701 \mathrm{CE}$, Japan constructed a State governed by the codes (律令國家) with the Emperor System that was equivalent to the status of Tang. Thus, Japan saw Silla as a representative vassal state in relation to themselves and established relations accordingly. ${ }^{22}$ This conceptualization is reflected in the

19 Shoku Nihongi 3, Emperor Monmu, Third year of Keiun (706) Spring, first month, Chŏnghae day, “金儒吉等還蕃 賜其王勅書曰 天皇敬問新羅王 使人一吉湌金儒吉薩湌 金今古等至 所獻調物竝具之 ......”.

20 Shoku Nihongi 3, Emperor Monmu, Third year of Keiun (706), eleventh month, Kyemyo day, “賜新羅國王勅書曰 天皇敬問新羅國王 朕以虛薄 謬承景運 漸無練石之 才 徒奉握鏡之任 .......”.

21 Shoku Nihongi 36, Emperor Konin, Eleventh year of Hoki, (780), second month, Kyŏngsul day, “潢新羅使還蕃 賜需書曰 天皇敬問新羅國王 朕以寡薄 纂業承基 理育蒼生 寧隔中外 .......”.

22 Ryounoshuuge 31, 公式令詔書式, “古記云 御宇日本天皇詔旨 對隣國及蕃國而調之 
reality of their diplomatic negotiations with Silla. As a result, in the diplomatic documents that the Japanese Emperor sent to the Silla King, the Japanese Emperor adopted the Weilaozhishu form utilized by the Tang Emperor.

On the other hand, there are currently no remaining documents that the Silla King sent to the Japanese Emperor at all. Thus, it is difficult to directly confirm how Silla perceived Japan and established relations with them through the use of an examination of the forms used in Silla's diplomatic documents. We can assume that the reason there are no remaining records of diplomatic documents sent from the Silla King to the Japanese Emperor is because from the outset, Silla did not create such pertinent documents. After the $8^{\text {th }}$ century, in diplomatic exchanges between Silla and Japan, the Silla King did not utilize national documents (國書) and exclusively sent envoys to verbally convey any messages. ${ }^{23}$ Throughout the entire $8^{\text {th }}$ century, Japan's Imperial Court continuously demanded that the Silla King produce official documents, particularly memorials to the throne, with regard to Silla's diplomatic conduct. This perception by Japan of Silla as a vassal was emphasized in the reality of Silla's own diplomatic exchanges. Nevertheless, unwilling to fulfill these demands by Japan, Silla did not utilize diplomatic documents and responded by exclusively sending envoys to verbally convey the Silla King's messages.

Although this will be addressed in greater detail in the following chapter, it was standard for Silla, who considered Japan to have an equivalent position as a neighboring country (隣國), according to the principle of diplomatic courtesy, to follow the formality of the relationship with a neighboring country and use an edict (㸚) form in writing and sending diplomatic documents to Japan. However, the Silla King's messages were

辭 問隣國與蕃國何其別 答隣國者唐 蕃國者新羅”.

23 Kang Ǔnyŏng, “Kodae ilbonŭi taesillagwan'gyewa sillaŭi kuksŏmunje(= The Issue of official government letters in Diplomatic Relationship between Shilla and Ancient Japan)," Han'guksayŏn'gu (Journal of Korean History) 179 (December 2017): 47-55. 
hard to accept for the court of Japan, which treated Silla as their vassal state. Even so, it was also impossible for the Silla King to take Japan's position into account and send a reply to Japan in the memorial (表) form that reflects a relationship between a superior and subordinate. Therefore, Silla's unique method of “verbal diplomacy (口頭外交)" in foreign relations with Japan was their countermeasure to prevent the inevitable diplomatic problems in with Japan caused by Silla and Japan's different viewpoints about their relations. While avoiding these problems, Silla intended to preserve relations with Japan for practical affairs. ${ }^{24}$

\section{Diplomatic Documents Between Silla and the Podŏk Kingdom}

Finally, it is necessary to examine the diplomatic documents exchanged between Silla and Ansŭng of the Podŏk Kingdom (Koguryŏ). The primary source available for examination is the one sent in the $10^{\text {th }}$ year of King Munmu's reign (670 CE), an investiture document (冊文) issued by King Munmu for the investiture of Ansŭng as the King of Koguryŏ.

C. First Year of Xianheng Era 咸亨 (670), Autumn August $1^{\text {st }}$, Sinch'uk day. The King of Silla hereby sends the order of the investiture to Ansŭng, the descendant of Koguryŏ. Your ancestor, King Chungmo (中牟王) founded his virtue at the North Mountain(北山), and merits at the South Sea. His dignity was well known in Blue Mound (the Eastern region from China, 靑丘), and his benevolent teaching spread to Xuantu (玄菟). His descendants continued his legacy through generations without end, the territory expanded to 1000-li wide, and its history was about to reach 800 years. [Yet,] by the time of the Namgŏn and Namsan brothers, disasters came from home and the brothers were divided. [As a result,] the country collapsed and the royal shrine vanished, while its people were in chaos without any-

24 Choi Hee-joon, "Sillaŭi ilbonsasin,” 398-399. 
where to go. Avoiding the dangers and hardships through mountains and fields, you entrusted your lonely self to the neighboring country. The agony in wandering is like Jin Wengong (晉文公), and resurrecting a collapsed country is like the achievements of Wei Hou (衛侯). People cannot live without a king, and the heaven always guides and looks after people. As you are the only rightful heir of the previous king, who else will supervise the ritual [at the royal shrine] but you? I send Ilgilch'an (一吉飡) Kim Sumisan (金須彌山) and others, convey the order of te investiture, and install you as the king of Koguryŏ. You will console and gather the remaining people, continue the royal lineage, and have a friendly relationship with us like brothers as a neighboring country. Be always respectful! Also, as I bestow 2,000 sŏk of rice, an armored horse, five rolls of silk with patterns (綾), 10 rolls of silk (絹) and hemp cloth made with fine thread (細布) each, and 15 ch'ing (稱) of cotton (綿), the king [of Silla] will receive them. ${ }^{25}$

On the surface, the passage appears to simply describe the investiture of the king of Koguryŏ by the king of Silla, but upon closer examination, it appears similar to the example of an emperor's investiture of feudal lords. The terminologies like ch'aek (investiture, 冊), or ch'aek (策), or pongwang (installing a king, 封王) in this document are used by the emperor in the investiture document. Moreover, the phrase "the king will

25 Samguk Sagi 6, Annals of Silla 6 King Munmu, Tenth year (670), Spring, first day of the month, “維咸亨元年歳次庚午秋八月一日辛丑 新羅王致命高勾麗嗣子安勝 公大祖中牟王 積徳比山 立㓛南海 威風振於青丘 仁教被於玄菟 子孫相継 本支不絶 開地千里 年將八百 至於津産兄弟 禍起蕭墙 覺成骨肉 家國破亡 宗社湮滅 生人波蕩 無所託心 公避危難於山野 投單身於鄰國 流離辛苦 迹同晉文 更興亡国 事等衛侯 夫百姓不可以無主 皇天必有以亚命 先王正嗣 唯公而已 主於祭祀 非公而誰 謹遣使一吉湌金須彌山等 就披策 命公爲高句麗王 公冝撫集遺民 紹興舊緒 永爲鄰國 事同昆弟 敬哉敬哉 兼送粳米二千石甲具馬一匹綾五匹絹細布各十匹綿十五稱 王其領 之'. 
receive them (王其領之)" that appears in the conclusion is analogous to idiomatic phrases used by the emperor whenever he sent investiture documents and goods. ${ }^{26}$ Yet in the body of the text, when King Munmu says to Ansŭng, "That we may forever be neighboring countries and spend it as brothers," thus indicating an equal relationship through the use of the term "neighboring country," is markedly different from the documents with the Tang Emperor. Thus, it is possible to say that in Document C, King Munmu of Silla and Ansŭng of Koguryǒ's relationship is reflected as vertical - as one of subordinate and superior. Nevertheless, the use of concepts such as "neighboring country" that indicate a horizontal relationship demonstrating Silla's dual position and behavior.

After this, in the $14^{\text {th }}$ year of King Munmu's reign (674 CE), Ansŭng was invested as the King of Podŏk (報德王). Then, in March of the $20^{\text {th }}$ Year of King Munmu's reign (680 CE), Silla made Ansung marry the daughter of Chapch'an (迎飡) Kim Ǔigwan, a niece of the king of Silla, and sent an edict letter. ${ }^{27}$ In May, Ansŭng elevated a memorial to the throne to King Munmu to express his gratitude. The following document $\mathrm{D}$ is the full text sent from Ansŭng of Podŏk to the Silla King Munmu in 680CE.

D. Your servant, Ansŭng, speaks(臣安勝言). Taeach'an (大阿湌) Kim Kwanjang 金官長 arrived, proclaimed an edict letter(㸚旨), and bestowed an edict letter to order me to marry your niece. All of these reached [me] on $15^{\text {th }}$, April, and I do not know what I should do, because I have mixed feelings of joy and fear. Thinking back, Emperor Yao (堯) made his

26 Yang Chŏngsŏk, "Silla kongsingnyŏngŭi wangmyŏngmunsŏyangsik koch'al," Han'gukkodaesayŏn'gu (The Journal of Ancient Korean History) 15 (May 1999): 175-177.

27 Samguk Sagi 7, Annals of Silla 7, King Munmu, Twentieth year (680), third month, “以金銀器及雜綵百段 賜報徳王安勝 遂以王妹妻之 [一云 迎湌金義官之女也] 下 教書曰", 
daughters marry Gui (縅), and the King of Zhou (周) give his princess away in marriage to Qi (齊); they did not hesitate to let his daughters marry ordinary people, revealing their holy virtue. Yet, your servant (Ansŭng) is merely a mediocrity without any talent or achievement. Fortunately, I have been lucky enough to be edified by a holy man, and received special favors [from you] time after time. There was no way to repay your favor even if I wanted to. Nevertheless, the great king (大王) gave me your favor again, and bestowed your relative on me. When flowers in bloom indicate a happy occasion, [your niece] will marry me in an auspicious day and month, and it is my fortune overnight that could not expect in 100 million years. It is truly an unexpected pleasure and occasion that I could not dare hope. How could this be the happiness only for my father or brothers? All my ancestors will be pleased. Since I did not receive the edict letter yet, I cannot dare visit you in person. Instead, I hereby submit a memorial to convey my words along with T'aedaehyŏng 太大兄 Yŏnmu 延武, as I could not suppress my joy. ${ }^{28}$

As explained in the previous chapter, a memorial is the form which a vassal uses to send a message to the Emperor. Ansŭng's memorial is also divided into three separate parts, with an introduction, body paragraph, and conclusion, and the introduction also begins with the standard "your servant, Ansŭng, speaks (臣安勝言), " generally matching the format of other memorials to the throne. Yet, while the Silla King refers to the Em-

28 Samguk Sagi 7, Annals of Silla 7, King Munmu, Twentieth year (680), Summer, fifth month, “臣安勝言 大阿湌金官長至 奉宣教㫖 并賜教書 以外生公 爲下邑内主 仍以四月十五日至此 喜懼交懷 罔知做真 髁以帝女降媛 王姬適齊 本揚聖徳 匪關九才 臣本庸流 行能無算 幸逢昌運 沐浴聖化 每荷殊澤 欲報無堦 重蒙天寵 降此姻親 遂即穠華表慶 肅催成德 吉月令辰 言歸弊館 億載難遇 一朝獲申 事非望始 喜出意表 豈惟一二父兄 實受其賜 其自先祖已下 定寵喜之 臣未蒙教旨 不敢直朝 無任㤝豫之至 謹遣臣大將軍太大兄延武 奉表以聞”. 
peror as “Emperor (皇帝),” or “Son of Heaven (天子),” or “Your Majesty (陛下)," appellations that match the emperor's caste in the memorials to the throne sent from the Silla to the Tang Emperor, he refers to the Silla King (King Munmu) as "Great King (大王)" in Ansŭng's memorial to the throne.

In fact, document $\mathrm{D}$ is a response to a message sent by King Munmu of Silla in March of the same year. An edict (Kyo, 呚) is a form of the orders from princes of the blood or feudal lords. From the early period, the kings of Silla used edicts to issue their royal orders. Accordingly, King Munmu officially wrote and sent a diplomatic document to the king of Podǒk kingdom, Ansŭng, as one of the Tang's feudal lords (king) in 680 CE. This illuminates the antinomy in which the Silla King utilized the Tang Emperor's investiture (冊), an exclusive form for an emperor's command, to install Ansŭng as King of Koguryŏ and Podǒk.

Through this examination, it is possible to say that the diplomatic documents exchanged between King Munmu of Silla and Ansŭng reflect their vertical relationship. King Munmu of Silla sent Ansŭng an investiture document, as if the emperor became a vassal servant, while Ansŭng used the memorial to the throne format when sending King Munmu a message as if he were a vassal servant sending a message to the emperor. On the one hand, King Munmu of Silla's usage of an edict form in sending diplomatic documents to Ansŭng reveals his adherence to the vassal position, displaying a "double" or "twofold" behavior. Even in document C, we can perceive the horizontal relationship between Silla and Koguryŏ through the Silla King's reference to Koguryŏ as a "neighboring country." Since Ansŭng also corresponded with this, the memorial to the throne that is Document D, instead of calling King Munmu the appellation that corresponded to the caste of the Emperor, he called him "Great King" instead. 


\section{Silla's Perception of the International Order and its Dual Position}

As seen in the aforementioned section, through examinations of various forms of diplomatic documents, within the official diplomatic relationship between the Tang Emperor and the Silla King, they recognized each other as "Son of Heaven (天子)" and "Your Vassal Servant (藩臣)," and established relationships accordingly. The tribute-investiture relationship was the foundation of this kind of bilateral relationship. In this relationship, while a small state provided tributaries to a powerful state, the ruler of the powerful state would endow the smaller country's ruler with a formal title or rank. As a result, the ruler's state to invest became a suzerain state to the invested ruler's state, and the invested ruler's state became a subordinate state (藩屬國). The result was the formation of a bilateral relationship between the two rulers of each country as one of the ruler and ruled, corresponding with the venerable (chongsok, 宗屬) relationship. This venerable relationship mentioned here is not equivalent to the subordinate (chongsok, 從屬) relationship, because it was a diplomatic relationship established between two independent countries, albeit a differential relationship. $^{29}$

Tribute and investiture were a symbolic ceremony that symbolized the relationship between China and its neighboring countries. This kind of symbolism was also demonstrated under the real strength of Confucian ideology. Through a single intercessional ceremonial space with his subjects, the emperor met vassal states' envoys to regularly and irregularly pay tribute, and symbolically reproduced an imperial structure that placed himself (the Emperor) at the center. ${ }^{30}$ Submission to Heaven (天下) was the most important evidence that he received the Mandate of Heaven. In

29 Kim Hankyu, Hanjunggwan'gyesa (History of China-Korea Relations) 1 (Seoul: Arŭk'e Press, 1999), 27-28.

30 Watanabe Shinichiro, trans. Mun chŏnghŭi and Yim Taehŭi, Ch'ŏn'gongŭi okchwa - Chungguk kodaejegugŭi chojŏnggwa ŭirye (Seoul: Sinsŏwŏn, 2002), 151-154. 
this sense, for the emperors of Hua (China, 華), who described themselves as the Son of Heaven with Mandate (受命天子), the submission of Yi (barbarian, 夷) was an essential prerequisite to prove the legitimacy of his authority. Thus, the Chinese emperors usually struggled to achieve all neighboring barbarians' tributes without exception, even if they were merely formality, and often caused economic losses. ${ }^{31}$

For the neighboring countries, one of the reasons they endured or volunteered in submission to China was to avoid invasion from the empire. On the other hand, by participating in the world order (天下秩序) supervised by the Son of Heaven, the rulers of the barbarians could show off their political authority at home and abroad. The official positions they received from the emperor in return for their formalities as his servants provided political authority for them to overwhelm their domestic competitors. Moreover, monopoly of the gateways to import the most advanced products from China became a condition for strengthening the base of their power. Additionally, the authority of the emperor could be partially used when the country tried to hold a dominant position in a conflict with a neighboring country, or to claim sovereignty over a region. ${ }^{32}$

In Silla's case, as it entered the Reign of Jindǒk in the mid- $7^{\text {th }}$ Century, Silla's indigenous era name and official robes were discarded and the Tang era names and official robes began to be utilized instead. Moreover, Confucianism was introduced as a new political ideology and in order to manifest this ideology, new offices in charge of formalities were created and maintained. Kim Ch'unch'u(金春秋), who led these kinds of reforms during Queen Jindŏk's reign, ascended the throne as the first jingol (眞骨) rank person and commenced a new era of the Silla dynasty known as the Middle Ages (中代). Hence, Silla was actively incorporated into a world order that was centered around Tang and with a Confucian formal system

31 Yi Sŏnggyu, "Chunghwasasanggwa minjokchuŭi," Ch'ŏrhak (Philosophy) 37 (May 1992): 49.

32 Yi Sŏnggyu, “Chunghwasasanggwa minjokchuŭi,” 49-50. 
as its foundation. ${ }^{33}$ Moreover, after Kim Ch'unch'u ascended the throne, the Silla kings, through the Tang Emperor's investiture, would receive an acknowledgement as the sole ruler of the territories in which they governed and by receiving official recognition, strengthened their symbolic position as the Emperor's vassal servant. Through this, they strengthened their differentiation from other jingol and nobles and secured legitimacy for their reign. ${ }^{34}$

E. My aunt T'an (坦) said to her subject, crying, "When I think back, [I believe] this country is different from the countries in the three directions [from China], because [we] changed our official attire, and adopted the imperial calendar (正朔), worshiping the emperor's state, and bringing the feudal lords' vassal states together. ${ }^{35}$

Document E is a portion of “「謝嗣位表」” written by Ch'oe Ch'iwŏn in the $11^{\text {th }}$ year of Queen Chinsong's reign $(879 \mathrm{CE})$. The mention of "aunt T'an" is a reference to Silla's $51^{\text {st }}$ Ruler, Queen Chinsŏng, while her "subject (臣)" refers to the crown prince Hyo (嶢), who later succeeded Queen

33 Silla's inclusion in the world order with Tang at the center was not a result of Tang's pressure. It was the result of Silla's active effort to survive from the crisis of losing in the conflict among the three kingdoms in Korean Peninsula. (Ha Ilsik, "Tang chungsimŭi segyejilssǒwa sillainŭi chagiinsik(Tang-Centric World Order and Silla's Self-Perception)," Yǒksawa hyŏnsil (History and Reality) 37 (September 2000): 77-78.

34 Silla did not give up the effort to continue the tribute-investiture diplomatic system until the end, even when their relationship was to the point of breakdown because of the war between Silla and Tang. See Kwŏn Tŏgyŏng, "Nadanggyosŏpsaesǒŭi chogonggwa ch'aekpong," Han'guk kodaegukkawa chunggugwangjoüi chogong ch'aekpong (Seoul: Koguryŏ yŏn'gu chaedan, 2006), 240-242. Presumably, Silla considered the practical influence of the tribute and investiture under the ideology of Confucianism.

35 Dongwenxuan 33, 表箋 謝嗣位表，“叔坦謂臣 涕隨言下曰 顧茲一境 異彼三方 何則 改服章 奉正朔 仰遵帝國 俯緝侯蕃”. 
Chinsŏng and became King Hyogong (孝恭王), the $52^{\text {nd }}$ ruler of Silla. According to the contents of the memorial, Queen Chinsong dictates to the crown prince Silla's previous days and uses the framework of "the emperor's state (帝國)” and “feudal lords' vassal states (侯蕃),” explaining the relationship between Tang and its neighboring countries. This arises from the epistemology of China's traditional sinocentric view and reconfirms Silla's use of the perception with Tang as Hua (華) and Tang's surrounding countries recognized as "Yi (夷)." Queen Chinsŏng emphasizes the other countries in the three directions from China, because Silla followed the emperor's state by changing their official attire and receiving the imperial calendar (正朔). Although Silla was one of the vassal states surrounding Tang at the time, they considered themselves as more superior to the remaining "uncivilized countries" by accepting the Tang's culture. ${ }^{36}$ In other words, Silla considered Tang's neighboring countries to be basically Tang's vassal states, including Silla itself.

Silla also perceived Japan to be one of the Tang's vassal states. Under this perception, Silla always tried to place Japan as their neighboring country, and performed a ceremony for a neighboring country (hangnye, 六禮) in diplomatic relationships.

F-1. Samhyŏn said, "Under the edict (㸚) from our king, we request to strengthen our old friendly relationship, and continuously send envoys to visit in courtesy (pingmun, 聘問)....” [The Japanese emperor's envoy] heard this and said, "In general, requesting to strengthen an old friendly relationship, and continuously sending envoys to visit in courtesy is for a ceremony to a neighboring country (元禮), not for a country in fulfilling their duty as a subject (供職). ${ }^{37}$

36 Ha Ilsik, "Tang chungsimŭi," 82-83.

37 Shoku Nihongi 33, Emperor Konin, Fifth year of Hoki (774), Third month, “三玄言曰 奉本國王教 請修舊好 每相聘問 ……問曰 夫請修舊好 每相聘問 乃似元禮之隣 非是供職之國”. 
F-2. When we received [and read] the document(狀) from Mitsu (三津) and others, it said "[we] came to only exchange friendship by order of the king." Then we opened the ham (a box of gifts 函) and read the official letter (牒), which only said, "if the ship of our envoys on their way to Great Tang (巨唐) for paying a visit in courtesy (kyobing, 修聘) drifts on your border, please do not stop or delay them but help them to pass through." The office in charge sent the envoy of the emperor to Ch'ŏngju (菁州) and asked in detail, but [Mitsu's word and the letter] were different from each other, so we could not verify the truth. Since it is not an envoy for exchanging friendship with a neighboring country (交隣), it is not a genuine gift. How could we accept such [a gift] without verifying the fact? ${ }^{38}$

Document F-1 is a portion of a conversation between the Silla envoy Kim Samhyŏn (金三玄) dispatched to Japan in the $10^{\text {th }}$ Year of King Hyegong of Silla's Reign (774 CE) and the Japanese envoy dispatched by the Japanese Emperor in order to confirm the purpose of the envoy's visit at Daizaifu (大宰府). Following this, the Silla envoy followed King Hyegong's "edict(敎)" and visited Japan in order to request "to strengthen our old friendly relationship, and continuously send envoys to visit in courtesy (修舊好 每相聘問).” The Japanese Emperor's envoy, hearing the purpose of the Silla envoy's visit, retorted that such a formality is not "for a country fulfilling their duty as a subject [供職之國]," but “a ceremony to a neighboring country [元禮之隣].” Through the Silla envoy's official mention, it is possible to confirm that Silla intended to establish an equal relationship, that is, as a neighboring country, with Japan in the middle of the

38 Shoku Nihon Kōki 5, Emperor Ninmyo, Third year of Jowa (836), Twelfth month, Chŏngyu day, “得三津等狀稱 奉承王命 専來通好 及開函覧皤 但云修聘巨唐 脫有使 船 漂着彼界 則扶之送過 無俾滯遏者 主司再発星使 般問丁寧 口與牒乘 虛實莫弁 㼛 非交隣之使 必匪由衷之賂 事無摭實 豈合虛受”。 
eighth century.

Document F-2 is a portion of an official letter (牌文) entitled "an Official Letter from Silla's Administration Department (新羅國執事省牌), ” which was issued in the $11^{\text {th }}$ Year of King Hŭngdŏk's Reign (836CE) from Silla’s Administration Department (Chipsasŏng, 執事省) and sent to Japan's the Great Council of State (Daijokan, 太政官). In the fall of 836 CE, a ship that carried a party of Japanese envoys, led by Ki-no-Mitsu (紀 三津), landed on Silla's southern shore. The royal court of Silla refused to allow this party to enter the capital and sent them back to Japan. F-2 was written by Silla to Japan's Great Council of State in order to notify the reason to send the envoys back. According to his letter, the reason for sending Ki-no-Mitsu's party back to Japan was that Silla thought they were not genuine envoys. At this time, they sent back the state letter (國 信) along with the party saying that, "Since it is not an envoy for exchanging friendship with a neighboring country (交隣), it is not a genuine gift. How could we accept such [a gift] without verifying the fact?" In this portion, it is to be emphasized that the official diplomatic document from Silla's Administration Department to Japan's Great Council of State referred to Japan as a neighboring country for exchanging friendship.

On the one hand, depending on the historical texts, there are records about the king of Silla who invested the rulers of neighboring countries and received tribute from them. As seen in the aforementioned analysis, in the $10^{\text {th }}$ Year of King Munmu's Reign $(670 \mathrm{CE})$, Ansŭng was installed as the King of Koguryŏ, and later invested as the King of Podŏk in the $14^{\text {th }}$ year of King Munmu's reign (674); these will be the most representative cases to show Silla's investiture of other rulers. Notably, the relationships between Silla and other countries resembled the venerable relationship (宗屬關係) between the Tang Emperor and the Silla King.

G. At first, they established a village to settle down, and visited to request to be a neighbor (隣接). Thus, your servant state (臣蕃, which refers to Silla) appointed the chief (酋長) Tae Choyŏng (大祚榮) as Taeach'an (大阿餐), which is the fifth rank. Later, in 
the $2^{\text {nd }}$ year of Xiantian (先天) (713CE), he received the order from the emperor to become the King of Parhae Prefecture (Parhae gunwang 渤海郡王). Recently, they are gradually ignoring our favor. We even heard that they are suddenly trying to perform a ceremony for a neighboring country (抗禮).

Document G is a portion of Ch'oe Ch'iwŏn's「謝不許北國居上表」. In the $4^{\text {th }}$ year of Qianning (乾寧) $(897 \mathrm{CE})$, Parhae's prince Tae Pongye, who visited Tang as an Envoy Celebrating the New Year (Hajŏngsa, 賀正使), submitted a document (狀) requesting the emperor to allow the envoys of Parhae to take the upper seats from the envoys of Silla. To this, Emperor Zhaozong of Tang rejected Tae Pongye's request and ordered the envoys of Silla to take the upper seats following previous precedents. Document D was a memorial written in the order from the king of Silla to express his gratitude to the emperor after the king received the report about the incident.

According to this document, around the time when Parhae was founded, Silla presented the Parhae king Tae Choyŏng the official position of Taeach'an, which was the fifth rank of Silla's prestige title. It was the $7^{\text {th }}$ year of King Hyoso (孝昭王) (698 CE), when Tae Choyŏng first established a kingdom and named it "Chin (震)", and it was the $12^{\text {th }}$ year of King Sŏngdŏk (聖德王) $(713$ CE) when Tae Choyŏng was invested as the King of Parhae Prefecture by the Tang dynasty. Therefore, Silla's bestowment of the prestige title would have occurred between 698 and 713 $\mathrm{CE}$, and the one who ordered this bestowment would be King Hyoso or King Sŏngdŏk. Since Parhae was in the territory outside the king of Silla's governance, this bestowment could be identified as a similar activity of an emperor bestowing a title to the ruler outside the emperor's ruling territory.

39 Dongwenxuan 33, 表箋 謝不許北國居上表, “初建邑居 來憑隣援 其酋長大祚 榮始授臣蕃第五品大阿餐之秩 後至先天二年 方受大朝龍命 封爲渤海郡王 邇來漸見 鼓恩 遽聞抗禮臣蕃”。 
H-1. (The $2^{\text {nd }}$ year of King Munmu's Reign, 662 CE) Todongŭmnyul (徒冬音律), Chwap'yŏng (佐平) and the ruler of T'amna Kingdom, submitted to us. They used Chwap'yŏng as their official position's name, because T'amna submitted to Paekche from the years of Wude (武德). Around this time, they (T'amna) surrendered and became our subject state (屬國). ${ }^{40}$

H-2. (The $19^{\text {th }}$ year of King Munmu's Reign, 679 CE) Silla sent envoys to T'amna kingdom and subjugated it. ${ }^{41}$

H-3. (The $2^{\text {nd }}$ year of King Aejang's Reign, 801 CE) T'amna kingdom sent an envoy to present tribute. ${ }^{42}$

Document H-1 is from the Annals of Silla in Samguk Sagi that the Tam'na kingdom surrendered to King Munmu of Silla and became their subject state. According to this, Tam'na kingdom was originally submitted to Paekche, but voluntarily became a subject state of Silla after Paekche collapsed due to the Silla-Tang alliance in $660 \mathrm{CE}$. According to the Annals of Paekche in Samguk Sagi, there are records that Tam'na offered local goods to Paekche, ${ }^{43}$ or apologized to the king of Paekche because they did not pay taxes. ${ }^{44}$ Considering these records, the king of Tam'na's

40 Samguk Sagi 6, Annals of Silla 6, King Munmu, Second year (662), “耽羅國主佐平徒冬音律 來降 耽羅自武德以來 臣屬百濟 故以佐平爲官號 至是 降爲屬國”.

41 Samguk Sagi 7, Annals of Silla 7, King Munmu, Nineteenth year (679), Second month, “發使略耽羅國”.

42 Samguk Sagi 10, Annals of Silla 10 King Aejang, Second year (801), “耽羅國遣使朝貢”.

43 Samguk Sagi 26, Annals of Paekche 4, King Munju, Second year (476), Fourth month, “耽羅國獻方物 王喜 拜使者爲恩率”.

44 Samguk Sagi 26, Annals of Paekche, King Tongsŏng, Twentieth year (498), Eighth month, “王以耽羅不修貢賦 親征至武珍州 耽羅聞之 遣使乞罪 乃止”. 
'submission' to Paekche mentioned in H-1 arguably is "pŏnsokkuk (submitted vassal state 蕃屬國)," a subject state offering tributes.

If this is the case, Tam'na's surrender to Silla and being a subject state in the second year of King Munmu's reign can be interpreted as continuing the superior and subordinate relationship with Silla, which Tam'na once had with Paekche. Although there are no records about their relationship after $\mathrm{H}-2$, it reappears 122 years later when the envoy from Tam'na offered tribute to Silla during the reign of King Aejang, which confirms that the venerable relationship between Silla and Tam'na continued in the Later Period (下代) of Silla. ${ }^{45}$

All these examples thus far demonstrate that the king of Silla, who claimed to be the Tang Emperor's vassal, possessed another position. Over his formal position as Tang's vassal state, Silla had the "submission to the stronger relationship (事大關係)" with neighboring countries like the Tang and Japan, but also established a 'venerable relationship (宗屬關係)' as a suzerain state with other countries like Podŏk Kingdom, Parhae in its initial founding, and Tam'na kingdom.

Within the context of international relations, Silla's dual positions were analogous to many cases that some barbarians (夷)'s claimed to be a suzerain state over the other body politics, using a similar logic and form of sinocentrism. First, during the North and South Dynasty period, the king was inverted by both the North and South Dynasties, Koguryŏ established a separated world (天下) with the king of Koguryŏ at the center and considered numerous political groups within this world as their 'subject people (屬民)', or 'barbarians(夷)' offering tribute to Koguryŏ. Although they did not claimed to be emperors, they referred to themselves as Great King (Taewang 大王), and used an independent era name. ${ }^{46}$

45 Choi Hee-joon, “T'amnagugŭi taeoegyosŏpkwa hangno (The T'amna State's External Negotiations and Routes)," T'amnamunhwa (T'amna Culture) 58 (June 2018): 18-19.

46 Noh T'aedon, “5segi koguryŏinŭi ch'ŏnhagwan” Han'guksasimin'gangjwa 3 (Seoul: Iljogak, 1988). 
For ancient Japan, after the $8^{\text {th }}$ century, they adopted China's code system and erected a new world order with the Japanese Emperor at the center. Japan designated the regions under the Emperor's royal influence (王 化) as Kenai (the region within the influence, 化內), while regions outside of the influence as Kegai (the region outside the influence 化外). It is perceived that Kenai consisted of the vassal states such as Silla, Paekche, Koguryŏ and Parhae, and the barbarians such as Emishi (遐夷) and Hayato (準人). In addition, Japan called their leaders Tenno (Emperor of Heaven, 天皇), a term which imitated China's emperor, and considered itself in an equal position with the Tang by claiming Japan to be a neighboring country to China, and using their own era name. Still, in the actual diplomatic relationship with the Tang, they sent envoys and offered tribute as a vassal state, even if they maintained the position of not receiving investiture.

After avoiding the Chinese dynasties' long domination after the $10^{\text {th }}$ century, Vietnam maintained the tribute-investiture relation in order to avoid a war with China, but domestically showed off consciousness of equality, calling their ruler an emperor and establishing their own era name. They also called their country Trung quốc (中國), and their people Hoa Dân (華民) or Hoặc (漢人). Additionally, they forced their neighboring small states to offer tribute; these cases show how Vietnam established their own typical world (天下). ${ }^{47}$

Through these examples, even if they established tributary-investiture relationships with Tang, Silla's behavior in receiving tribute from neighboring countries can be understood as one universal phenomenon taking place within the field of premodern East Asia's sinocentricism. Yet, after the middle of the $7^{\text {th }}$ century, Silla no longer called its own ruler as an emperor nor used their own era name. Moreover, even though Silla continued to invest rulers of neighboring countries and received tribute, the diplomatic documents of the Silla kings issued in the context of this process used the edict (敎) form and mentioned 'exchanging friendship with a

47 Yu Insŏn, "Chungwŏlgwan'gyewa chogongjedo kasanggwa silssang," Yǒksahakpo 114 (June 1987). 
neighboring country (交隣)' in their content. In this sense, it is difficult to say that Silla openly established an independent world (天下) like Koguryŏ, Japan, and Vietnam.

To summarize, Silla incorporated an international order that was constructed with Tang at the center through the tribute-investiture system and actively aligned with the formal position of Tang's vassal state. In the same context, other countries such as Japan and Parhae that were included within this international order were also basically recognized as Tang's vassal states. Therefore, although Japan treated Silla as its own vassal state, Silla addressed Japan as if it were in an equivalent position to itself by referring to it as a neighboring country in its diplomatic relations. Moreover, Silla's perception of the international order was the result of consideration of diplomatic benefits and international status they could gain from maintaining close relations with Tang. Domestically, it reflected the king of Silla's intention to maintain the legitimacy of succession, which was granted by the symbolic position of the Tang Emperor's vassal servant.

On the other hand, Silla considered itself in a suzerain position and used its authority over neighboring political powers that did not directly have relations with Tang such as Podŏk, Tam'na and early Parhae. As examined above, Tang, Koguryŏ, Japan, and Vietnam, Silla did not want to miss the chance to show off their vassal states submitting to them, which had certain domestic political effectiveness. Nevertheless, the strength of Silla's proclamation of the 'world' with Silla at the center was remarkably weak, and the method was exceptionally cautious. Probably, it was because for the kings of Silla, the benefits procured by acting as the symbolic position of the Tang Emperor's vassal was far greater to creating a world with Silla at the center and other vassal states.

\section{Conclusion}

This paper has sought to examine the establishment of relations be- 
tween Silla and its neighboring countries through the examination of diplomatic documents and its formalities exchanged between them. The diplomatic documents that the Tang Emperor sent to the Silla King were written in Weilaozhishu and Weilaozhishu forms in order to convey his decrees, and both the content and form of these documents reflect that the relationship between the two was that of a subordinate vassal state and superior imperial state. Moreover, all diplomatic documents that the Silla King sent to the Tang Emperor were written in the form of a memorial, a deliberate decision that reflected a vassal uplifting a document to his emperor. With the Japanese Emperor choosing Weilaozhishu form to address the Silla King to send diplomatic documents; this signifies that Japan considered itself in the position of the emperor's state and Silla to be in the position of the vassal state. On the other hand, in his relationship with Japan, the Silla King did not utilize diplomatic documents and instead only used envoys to send messages and convey his intentions; this was Silla's diplomatic strategy to avoid the situation that Japan one-sidedly demanded memorials to the throne from the Silla King in order to maintain their relationship. Moreover, when sending documents to Ansŭng of Bodeuk, King Munmu of Silla would use the investiture document utilized by emperors, and Ansŭng would reply using the memorial form. Even when looking at the protocols of these diplomatic documents, we can presume that the bilateral relationship between them was the subordinate and superior one of a suzerain and pŏnsokkuk. Yet, King Munmu also used an edict(敎) format in some of his diplomatic documents sent to Ansŭng, intermingling expressions that reflected a horizontal relationship between the two countries.

In the same vein, the Silla King would regulate himself as the Tang Emperor's vassal servant in their official diplomatic relations, and the Tang Emperor also reciprocated by establishing relations with the Silla King as his own vassal. Taking itself as the Tang's vassal servant, Silla would also recognize Tang's neighboring countries as vassal states (with itself included) and established relationships with them accordingly. Because of this, Silla would also utilize conventions that signified it considered itself on an equal position with Japan in its diplomatic relations with 
them and treated them as a neighboring country.

On the other hand, the records confirm that the king of Silla installed the monarchs of neighboring countries, thereby receiving tributary from them and from the position of a suzerain state, maintained the appearance of the venerable relationship. This can be understood as another formal position the king of Silla chose, who claimed to be a vassal of the Tang emperor. This phenomenon was universal in premodern East Asia.

Still, in comparison to Koguryŏ, Japan, and Vietnam, the strength of Silla's perception of the 'world' with Silla at the center was relatively weak, and its way of practicing such a perception was far more cautious; it was the result of Silla's overall consideration of the power of the Chinese dynasties, their proximity to Silla, and effectiveness of the symbolic titles like a vassal of the Chinese emperor for the king of Silla in domestic politics.

\section{References}

\section{Primary Sources}

1. Dongwenxuan

2. Quan Tang Wen

3. Ryounoshuuge

4. Samguk sagi

5. Shoku Nihongi

6. Tang Liudian

7. Wenguan Cilin

\section{Secondary Sources}

8. Ch’ae, Miha. "chinsŏngwang chŏnhuŭi oegyomunsŏwa silla (Diplomatic Documents Before and After the Reign of King Jinseong in Silla)," Han'guksayŏn'gu (Journal of Korean History) 179 (Decem- 
ber 2017): 111-112.

9. Ch'oe, Kwangsik. "haeje ch'oech'iwŏn'gwa kyewŏnp'ilgyŏngjip," Koun ch'oech'iwŏn sŏnsaeng munjip 1 (2016), 37-38.

10. Choi, Heejoon. "T'amnagugŭi taeoegyosŏpkwa hangno (The T'amna State's External Negotiations and Routes)," T'amnamunhwa (T'amna Culture) 58 (June 2018): 18-19.

11. Choi, Heejoon. "Sillaŭi ilbonsasin yŏngjŏp chŏlch'awa ŭiryejŏk t'ŭkching (Silla's Reception Procedure for Japanese Envoys and Ceremonial Characteristics)," Sillasahakpo 45 (April 2019).

12. Chŏn, Tŏkchae. "Sillaŭi taeoeinsikkwa ch'ŏnhagwan (Shilla's View of Foreign Situations and Its Perception of the Outer World)," Yŏksamunhwayŏn'gu (Journal of history and culture) 20 (June 2004).

13. Chŏn, Tŏkchae. '8segi sillaŭi taeiroegyowa tongasia insik," Ilbonhagyŏn'gu 44 (February 2015).

14. Ha, Ilsik. "Tang chungsimŭi segyejilssŏwa sillainŭi chagiinsik(TangCentric World Order and Silla's Self-Perception)," Yŏksawa hyŏnsil (History and Reality) 37 (September 2000): 77-78.

15. Hwang, Wiju. "Parhae oegyomunsouŭi silssanggwa kŭ munch'ejŏk t'ŭkching (The real states of diplomatic documents of Balhae (渤海) and the characteristics of their literary styles)," Taedonghanmunhak 26 (June 2007): 217-218.

16. Fairbank, John K. and S. Y. Teng. "On the Ch'ing Tributary System," Harvard Journal of Asiatic Studies 6 (June 1941).

17. Fairbank, John K. "A Preliminary Framework," in The Chinese World Order: Traditional China's Foreign Relations, Harvard University Press, 1968).

18. Shuichi, Kaneko. "Toudai no kokusai bunsho keishiki nit suite," Shigaku zatsushi 83 (1974).

19. Kang, Ǔnyŏng. "Kodae ilbonŭi taesillagwan'gyewa sillaŭi kuksŏmun$\mathrm{je}$ (= The Issue of official government letters in Diplomatic Relationship between Shilla and Ancient Japan)," Han'guksayŏn'gu (Journal of Korean History) 179 (December 2017): 47-55.

20. Kim, Ch'angsŏk. "T'ongilssillaŭi ch'ŏnhagwan'gwa taeil insik," 
Yŏksawa hyŏnsil (History and Reality) 56 (June 2005).

21. Kim, Chongpok. "Silla's Diplomatic Tactics in Using Tensions Between Balhae and Tang in the Early $8^{\text {th }}$ Century," The Daegu Historical Review 126 (February 2017): 27-28.

22. Kim, Chongwan. Chunggungnambukchosayŏn'gu - chogong kyobinggwan'gyerŭl chungsimŭro (Seoul: Iljogak, 1995), 106-107.

23. Kim, Hankyu. Hanjunggwan'gyesa (History of China-Korea Relations) 1 (Seoul: Arŭk'e Press, 1999), 27-28.

24. Kim, Han'gyu. "Kodae tongasia segyejilssǒŭi kujojŏk t'ŭksŏng (Structural Characteristic of the World Order of the Ancient East Asia)," Tongasia yŏksaŭi hwallyu (Reflux of the East Asian History) (Seoul: Chisiksanŏpsa, 2000).

25. Kim, Sŏnggyu. "Miguk mit ilbonesŏ chŏnt'ongjunggugŭi segyejilssŏe kwanhan yŏn'gusawa kŭ t'ŭkching pigyo (A survey and comparison between their characteristics of studies on the traditional Chinese world order in America and Japan)," Yǒksamunhwayŏn'gu (Journal of history and culture) 32 (February 2009).

26. Kwŏn, Tŏgyŏng. "Nadanggyosŏpsaesǒŭi chogonggwa ch'aekpong," Han'guk kodaegukkawa chunggugwangjoŭi chogong ch'aekponggwan'gye, (Seoul: Koguryŏyŏn'gujaedan, 2006).

27. Mun, Ansik. "Nambukkuksidaeronŭi hŏsange taehayŏ sillawa pa rhaeŭi ch'ŏnhajilssŏe kiinhan sanghoinsigŭl chungsimŭro," Han'gukkodaesayŏn'gu (The Journal of Korean History) 19 (September 2000); Han'gukkodaesawa malgal(Ancient Korean History and Malgal) (Seoul: Hyean, 2003).

28. Hiroichi, Nakamura. Toudai Sei chou kenkyu (Study of Zhi and Chi during the Tang Dynasty Period), (Kyuukoshoin, 1991).

29. Hiroichi, Nakamura. Zui Tou ougen no kenkyu (Study of the King's Words in Sui and Tang dynasty), (Kyuukoshoin, 2003).

30. Sadao, Nishijima. "Tou Asia sekai to Sakuhou taisei - roku hachi seiki no Tou Asia (the World of East Asia and Investiture System East Asia from $5^{\text {th }}$ to $8^{\text {th }}$ century)," Nihon Rekishi (History of Japan) 2 (1962). 
31. Sadao, Nishijima. "Tou Asia sekai no keisei (Formation of the World of East Asia)," Sekai Rekishi (World History) 4 (1970).

32. Noh, T'aedon. "5segi koguryŏinŭi ch'ŏnhagwan” Han'guksasimin'gangjwa 3 (Seoul: Iljogak, 1988).

33. Pang, Hyangsuk. "Kodae tongasia ch'aekpongjogongch'ejeŭi wŏnhyŏnggwa pyŏnyong” Hanjung oegyogwan'gyewa chogongch'aekpong (Diplomatic Relationship between Korea and China, and Tribute-investiture) (Seoul: Koguryŏ yŏn'gujaedan, 2005).

34. Yun, Peter. "Sŏgu hakkye chogongjedo ironŭi chungguk chungsimjŏk munhwaron pip'an (A Critique of Sinocentric Culturalism of the Tribute System Model), The Journal of Asiatic Studies), ' Aseayŏn'gu (The Journal of Asiatic Studies) 45, no.3 (September 2002).

35. Masashi, Sakayori. "Kodai Tou Asia shokoku no kokusai ishiki chukka ishiki o chushin shite," Rekishigaku kenkyu (Study of History) (November 1982).

36. Shinichiro, Watanabe. trans. Mun chŏnghŭi and Yim Taehŭi, Ch'ŏn'gongŭi okchwa - Chungguk kodaejegugŭi chojŏnggwa ŭirye (Seoul: Sinsŏwŏn, 2002), 151-154.

37. Fumito, Yamada. "Silla sŏngdŏgwangdaeŭi taeilgwan'gyewa wangsŏngguk (Relationship with Japan and 'Wang Seong Guk(王城 國)' in King Seong-deok's(聖德王) Era of Silla), Han'gukkodaesayŏn'gu (The Journal of Korean History) 87 (September 2017).

38. Yang, Chŏngsŏk. "Silla kongsingnyŏngŭi wangmyŏngmunsŏyangsik koch'al," Han'gukkodaesayŏn'gu (The Journal of Ancient Korean History) 15 (May 1999): 175-177.

39. Yi, Sŏnggyu. "Chunghwasasanggwa minjokchuŭi," Ch'ŏrhak (Philosophy) 37 (May 1992): 49.

40. Yu, Insŏn. "Chungwŏlgwan'gyewa chogongjedo kasanggwa silssang,” Yǒksahakpo 114 (June 1987). 
〈Abstract〉

\section{Silla's Perception of the International World Order as Seen through Diplomatic Documents}

Heejoon Choi

This paper is an attempt toward structural understanding about Silla's recognition of the international order under the Sinocentric diplomacy system in East Asia from the seventh to tenth century through analyzing diplomatic documents. It proved that the Silla king regulated himself as the Tang Emperor's vassal servant in their official diplomatic relations, and the Tang Emperor also reciprocated by establishing relations with the Silla King as his own vassal. Taking itself as the Tang's vassal servant, Silla would also recognize Tang's neighboring countries as vassal states (with itself included) and established relationships with them accordingly. Because of this, Silla would also utilize conventions showing that it considered itself on an equal position with Japan in its diplomatic relations with them and treated them as a neighboring country. On the other hand, the records confirm that the king of Silla installed the monarchs of neighboring countries, thereby receiving tributary from them and from the position of a suzerain state, maintained the appearance of the venerable relationship. This can be understood as another formal position the king of Silla chose, who claimed to be a vassal of the Tang emperor.

Keywords: Silla, Tang, Japan, diplomatic documents, international order, tribute, investiture, suzerain state, vassal state, Tributary System, Investiture, Suzerain, Submission to the stronger, Kyorin (exchanging friendship with a neighboring country, 交隣) 


\section{〈국문초록〉}

\section{외교문서를 통해 본 신라의 국제질서 인식}

최희준 (단국대학교 박사후연구원)

본 논문은 신라가 주변국과 주고받았던 외교문서의 형식을 분석하여 7 10세기 동아 시아의 외교 시스템 속에서 신라가 갖고 있었던 국제질서 인식에 대한 구조적 이해를 도모한 결과물이다. 신라국왕은 당과의 공식적인 외교관계에서 스스로 당황제의 蕃臣 으로 규정하였고, 당황제 또한 신라국왕을 자신의 번신으로 관계설정하고 있었다. 신라 는 당의 번국이라는 지위를 기본으로 삼아 자신을 포함한 당 주변의 국가들에 대해서 는 당의 번국으로 인식하여 관계설정하였다. 한편, 기록에 따라서는 신라국왕이 주변국 의 군주를 책봉하거나 그로부터 조공을 받는 등 종주국의 지위에서 종속관계를 맺는 양상이 확인되기도 한다. 이는 당황제의 번신이라는 지위를 표방했던 신라국왕이 취했 던 또 하나의 예적 지위로, 전근대 중화사상의 자장 속에서 전개되었던 동아시아사의 보편적 현상 중 하나로 이해된다.

주제어: 신라, 당, 일본, 외교문서, 국제질서, 조공, 책봉, 종주국, 번국, 사대, 교린 
